\title{
Adorno on leadership
}

\author{
Steven Dandaneau
}

Vice Provost for Undergraduate Studies and Associate Professor of Sociology, Kansas State University, Manhattan, KS, USA

'... the ideas of democracy and leadership have to be given a more concrete meaning so as to prevent them from becoming mere phrases which may finally cover the very opposite of their intrinsic meaning.'

T.W. Adorno (1950 [1965], p. 419)

If Theodor W. Adorno - recognized as among the most critical and uncompromising of twentieth century philosophers ${ }^{1}$ - were to have crafted a leadership studies curriculum, what would it have looked like? Speculation is unnecessary. In his 'Democratic leadership and mass manipulation' (1950 [1965]), Adorno offers a theory of 'democratic leadership' as well as basic instruction on how best to advance democratic leadership. The author of notoriously challenging texts, lectures, and musical scores, Adorno's theory of leadership is, in a departure, nothing if not accessibly rendered and, in fact, amenable to succinct summary:

- Democracy is an ideal rather than a reality under conditions of modern mass society.

- Modern mass society contains both latent democratic and latent anti-democratic potentials.

- 'Democratic leadership' rends the anti-democratic of its power to deceive and manipulate.

This research note is dedicated to two tasks: (1) to provide further albeit concise elucidation of Adorno's theory, and (2) to provide statement of research questions inspired by Adorno's mid-century theory but meant to address today's principal leadership challenge. Arguably, Adorno's thinking - and that of his kindred spirits ${ }^{2}$ - deserves sustained attention from students of leadership. My goal is to encourage further study.

1. The literature on Adorno is vast and uneven; no effort is made here to assess it. For the neophyte, however, I offer suggested readings. On Adorno's biography, see Müller-Doohm (2005). For an historical treatment of the early 'Frankfurt School,' in which Adorno was an essential figure, see Jay (1973). For a study of the unique contours of Adorno's thought that is equal to its subject, see Jameson (2007). For an application of Adornoian thought in empirical research, see Dandaneau and Falcone (1998). For notable engagements with Adorno in divergent theoretical research, see Wolin (2006) and Said (2007). For a critique of Adorno's philosophical premises, see the competing perspectives offered in The Positivist Dispute in German Sociology, edited by Adorno et al. (1976). As is said often enough, there is no substitute for reading Adorno's original work. Adorno's oeuvre includes several classics, among them, with Frenkel-Brunswik, Levinson, and Sanford, The Authoritarian Personality (1951 [1993]), Minima Moralia (1951 [1987]), Negative Dialectics (1966 [1973]), Aesthetic Theory (1970 [1997]), and, with Max Horkheimer, Dialectic of Enlightenment (1944 [2007]). This is not to suggest, however, that Adorno's numerous other works are lesser.

2. Adorno's kindred spirits included Samuel Beckett, Alban Berg, Fritz Lang, even John Dewey and, in another direction, Friedrich Nietzsche, but here I refer principally to members 


\section{ADORNO'S THEORY}

"The concepts of "leadership" and "democratic action" are so deeply involved in the dynamics of modern mass society that their meaning cannot be taken for granted in the present situation' (Adorno 1950 [1965], p. 418 3). So begins Adorno's essay, 'Democratic leadership and mass manipulation,' a merely 21-page text which appeared in Alvin W. Gouldner's over 700-page edited Studies in Leadership: Leadership and Democratic Action (1950). Despite the contributions of so many leading lights, among them Adorno as well as such immediately name-recognizable figures as Bell, Bendix, Glazer, Lazarsfeld, Lewin, Lipset, Lowenthal, Merton, Nisbet, Riesman, Selzinck, Warner, and Whyte; despite its editor's growing influence and notoriety; despite its interdisciplinarity, drawing insights from sociology but also psychology, philosophy, history, law, and politics; despite the fact that the volume was reissued in 1965 , just in time, as it were, for close inspection by would-be 1960s social movement democratic leaders; despite the combination of so many favorable factors, Studies in Leadership, and Adorno's contribution therein, has had seemingly little evident influence on the development of theory in leadership studies. ${ }^{4}$

Part of the reason for this obscurity lies, no doubt, in Studies in Leadership's critical character, which is especially pronounced in Adorno's essay. Notably, in statement of his first thought on the subject, Adorno places into question that which is usually taken for granted as the starting point for further study and reflection, namely that democracy and democratic leadership can be said to exist. Adorno's litmus test is empirical: he asks, implicitly, do 'intellectual autonomy' and 'self-determination,' the hallmarks of democracy, obtain generally among 'the people,' or does something lesser or even contradictory intervene? To what extent do 'prejudice,' 'political naiveté,' and other forms of self-deception and debasement of reason and freedom characterize the dominant social milieu (p. 451)? Adorno's answer to such questions is suggested by his assertion that 'a thought-controlling mass culture has become almost universal' (p. 420). Note: the qualification is as important as the principal thrust of the statement.

Having made affirmative reference to Rousseauian ideals at the outset, Adorno then follows Michels in observing that the sheer scale of the modern societal order, the concentration of power resulting from the rise of giant bureaucracies, and the corruption

of the 'Frankfurt School' of Critical Theory, especially Max Horkheimer, Herbert Marcuse, and Leo Lowenthal, and to others closely affiliated with the Institute for Social Research, particularly Walter Benjamin. On Adorno's relationship with his Frankfurt School colleagues, one might profitably consult Claussen (2003 [2008]), whereas probably the most comprehensive study on the Frankfurt School as such is Wiggershaus (1994).

3. Unless stated otherwise, all subsequent page references will be to Adorno (1950 [1965]).

4. Admirable for its theoretical breadth, including Marxian theory, Burns (1978 [2010]) makes no mention of Adorno. Sharing Adorno's attention to the significance of 'loss' (see Pensky 1997), Heifetz and Linsky (2002) nonetheless make no direct connection. The often excellent Bennis and Goldsmith (2010) suggest that Adorno's theory of leadership flowed somehow from Lewin, which is a claim that begs further elucidation. And while Drucker never to my knowledge made mention of Adorno, Gilman (2006) briefly and suggestively relates the two in his study of Drucker as the 'prophet of post-Fordism.' Adorno's theory of democratic leadership is, however, occasionally dutifully referenced in literature dedicated to the study of leadership, as it is in Choi (2007), but here as typically without elucidation. The lacuna is no less pronounced in the literature on Adorno: for example, Benzer's (2011) excellent study of The Sociology of Theodor Adorno has nothing explicit, much less elaborate, to say about Adorno's theory of democratic leadership, although Benzer is unmistakably aware of it. 
which systematically ensues from both, means also that 'the truly democratic functioning of leadership, as far as it had ever been achieved in reality, has vanished' (p. 418). Adorno expressly does not wish to convey, however, that democratic tendencies are therefore non-existent or that democratic leadership is moot, for he nods to formal democratic mechanisms, including 'the ballot,' and acknowledges 'the fact that in decisive situations "grass-root" democracy, as opposed to official public opinion, shows amazing vitality' (ibid.). Rather than dismiss the need for, and the potential for, democratic leadership, Adorno's narrative reads this way: 'leadership itself, frequently severed from the people, became increasingly rigid and autonomous,' and 'concomitantly, the impact of leadership upon the masses ceased to be entirely rational and plainly revealed some authoritarian traits which are always latent where power is wielded by a few over many' (p. 419). With reference to the rise of modern civilization and its discontents (and with explicit reference to Freud), Adorno posits that modern mass society creates an irrational, false social-psychology between leaders and led, and that, therefore, democratic leadership is needed to resist the spiral of democracy into its opposite. This requires, above all, a form of immanent critique, wherein 'it is the function of democratic leadership to make the subjects of democracy, the people, conscious of their own wants and needs as against the ideologies which are hammered into their heads by the innumerable communications of vested interests' (p. 420, emphasis in original).

From the vantage of the immediate aftermath of the war - and I ask the reader to conjure for themselves the particulars of this still-abundantly consequential, and for many of us, still-burning historical context - Adorno observes that "hollow and inflated leader figures such as Hitler and Mussolini, invested with a phony "charisma," are the ultimate beneficiaries of these societal changes within the structure of leadership' (p. 419). Anti-democratic leaders, as well as those who unwittingly ape them or who are blithe to the latent authoritarian character of even formally democratic institutions and processes (see also Marcuse 1964), are able to manipulate real and imagined powerlessness among 'the masses' - those who are 'lonely, isolated, and, in many ways, frustrated people' (p. 435) - to effect a type of 'authoritarian identification and introjection' wherein these same peoples' 'longing for spontaneous, genuine relationships, for love, is seized upon by the cold-blooded promoters of the inhuman' (pp. 419 and 435). In particular, Adorno addresses the authoritarian agitator's guise of the 'great little man' and the depth psychology out of which 'anti-Semitism' became in Germany, the United States, and elsewhere, the 'spearhead of fascism' (pp. 434 and 424). He argues that democratic leadership must learn to use 'lever effects' (à la Freud) and other sources of humanistic and social scientific knowledge in order to release genuine democratic impulses from the domination imposed by mass manipulation (p. 429). 'The very fact that people suffer from universal manipulation is used for manipulation' disgusts Adorno and gives his theory of leadership a moral as well as a political character (p. 435). For Adorno, democratic leadership is action based in the critique of ideology and undertaken in order to realize democratic ideals in practice. Leadership is rendered, not in terms of critical theory, but as critical theory. ${ }^{5}$

5. It is beyond the scope of this research note to explicate the meaning of 'critical theory.' Helpful explanatory sources include Geuss (1981), who offers a notably concise treatment, and Bernstein (1978), who elaborates greater context. The classic original sources, however, are Horkheimer (1937 [1972]) and Marcuse (1937 [1968]), which should be critically compared to Horkheimer and Adorno (1944 [2007]) and Adorno (1966 [1973]). 
Having laid out his basic perspective, it may be observed that Adorno offers a number of concrete postulates and lessons for would-be democratic leaders. Among those which might be gleaned are these:

- Exclusively rational criticism of anti-democratic forces ('give them the facts') forgets that anti-democratic forces work at the level of unconsciousness as well as consciousness (p. 420).

- While democratic leaders may be tempted to "make use" (Adorno places this phrase in scare quotes to highlight its only apparently anodyne significance) of available social technologies (for example, mass and social media) for manifestly democratic ends (what Adorno calls 'democratic manipulation'), the 'cynical attitude' behind such efforts 'would bring about an inconsistency between ends and means which would impair the sincerity of the whole approach and destroy its inherent conviction' (pp. 420 and 421).

- As a result of their encounter with modern scientific technology, modern people are imbued with a reactive rationality which leaves them 'alert, skeptical, and resistant against make-believes of all kinds - frequently they remain indifferent even to the highest pressure of propaganda, if important issues are at stake - that there can be no doubt about the existence of strong countertendencies against the all-pervasive ideological patterns of our cultural climate' (p. 420).

- 'Democratic enlightenment has to lean on these countertendencies which, in turn, should draw on all the resources of scientific knowledge available to us' (ibid.).

- 'The less the people believe in political integrity, the more easily can they be taken in by politicians who rant against politics' (p. 423).

- Given 'the mass potential of autonomy and spontaneity which is very much alive' (p. 423), democratic leadership's greatest calling is to 'foster self-reflection' and, by another name, 'introspection,' and this, at the juncture where 'anti-democratic stimuli and subjective dispositions coincide' and 'both stimuli and effects are heavily concentrated: that of race hatred in general, and present-day totalitarian anti-Semitism in particular' (p. 424).

- Thus, 'vaccines against authoritarianism' include elucidation of the manipulative techniques which anti-democratic leaders use to incite 'race hatred' and similar irrationalities (p. 429). Adorno calls this approach 'Operation "Boomerang,", hoping to "turn the indignation of the prejudiced person against a truly adequate object ...', that is, manipulation itself (p. 434).

Adorno concludes his essay by appending two and one-half pages of an untitled 'manual' which he and Max Horkheimer authored for the purpose of revealing for a would-be general readership the propaganda techniques used by the advocates of anti-democratic society (for example, Martyr Hero, If Only You Knew) (see pp. 436-438). ${ }^{6}$ It would seem that Adorno's own democratic leadership included writings designed to help readers become aware of systematic manipulation in the hope that this would open space for the realization of, and free invention of, their real wants and desires. At other times, Adorno offered public lectures and radio addresses, participated in protests, served as an evaluator of would-be school philosophy teachers, and supported colleagues, including especially younger colleagues, as they intervened

6. See Aspects of Sociology by the Frankfurt Institute for Social Research (1973), which contains much of Horkheimer and Adorno's effort to contribute accessible yet critical 'lever effect' materials for democratic consumption. 
politically in public life (see Adorno 2005 for examples of his engagement with publics; and see especially Mariotti's (2013) germane discussion of 'Adorno on the radio: democratic leadership as democratic pedagogy,' as her study also makes direct and sustained use of Adorno's seminal 'Democratic leadership and mass manipulation').

Before leaving explication of Adorno's essay, it is important to consider his own stipulated doubts. More than once Adorno concedes something to the effect, 'nevertheless, attempts will have to be made' to do such-and-such (p. 429). He is abundantly self-aware of the fragility of democratic leadership. He notes, first, the possible objection that his emphasis on the 'subjective element' is misplaced (p. 430). If one reads 'the field of power-politics' as overwhelmingly capable of quashing democratic tendencies, or if one subscribes to what Adorno believes is a mistakenly hypostatized view of Society (with a capital ' $S$ '), then one might doubt the validity of Adorno's advocacy for a democratic leadership attuned to the liberatory potential enclosed within the social psychology of mass society (ibid.). But even if one accepts the pragmatic importance of social psychology, it does not automatically follow, Adorno concedes, that debunking à la Operation Boomerang will produce a 'depth-charge effect' (ibid.). It is not sufficient to merely theorize the irrational, or to present the irrational rationally. Adorno understands this, but adds: 'while these objections denote a definite limitation of our approach, they should not discourage us altogether' (p. 431). Again, the qualification is the message.

Why should we be not altogether discouraged? The worse things are - the more political naiveté, the more alienation - the greater, Adorno emphasizes, 'the shock evinced by ... dawning awareness ...' (p. 431, emphasis in original). And the greater the shock, the greater the possible 'lever effect.' But what if a therapeutic shock refuses to materialize, as theorized? Even initial problematizing of self and world, thinks Adorno, leaves the heretofore prejudicial citizen with a 'somewhat bad conscience' and an internal 'conflict situation,' and this 'brings about a certain weakening of ... [prejudice's] violence,' and, ultimately, a less fanatical individual (p. 431). Besides, even the most defensive person actually longs for self-knowledge and the relief that could come with acceptance of one's self, one's life, one's flaws alongside appreciation of one's gifts - this, rather than repressing the truth of oneself in favor of falsehoods and palliatives. Even narcissism can help: people like to 'feel important,' Adorno notes, and so might be attracted to discourse about their inner lives (pp. 432-433).

In sum, Adorno's theory of democratic leadership may be rendered concisely: under conditions of modern mass society, democratic leadership must be defined negatively as the critique (intellectual and practical) of authoritarianism (or anti-democracy). That is, under prevailing social conditions - and are they improved since 1950? - would-be democratic leaders cannot afford to ignore the micrological preconditions of democracy nor, and it amounts to the same thing, stray from steady attention to the wellsprings of mass authoritarianism.

The leadership studies curriculum which may be extrapolated would require the would-be democratic leader to struggle with a range of humanistic and scientific materials to learn how to best identify and continuously root out the psycho-emotional (unconscious as well as conscious) distortions that result from purposeful as well as systematic "mass manipulation.' Not to put too fine a point on it, the goal would be to educate the leader for the capacity and drive to produce in others critical intellectual openings in which there might emerge self-knowledge and free self-determination. Prerequisites for such work are careful and honest as well as informed and theoretically guided introspection.

Such a curriculum, formal or otherwise, would be equally invested in the study of history-making or human self-becoming, and the temporal and spatially diverse range 
of human culture set against the rise of modern mass society. One might say that the student of democratic leadership must acquire a rich understanding of the characteristic longings and frailties of the human condition, especially as these have been given exaggerated character under the extreme self-imposed circumstances of the contemporary Anthropocene. And all this, it must be emphasized, alongside development of a keen self-awareness which rejects any number of gratifying, comforting, easy, yet false self-perceptions.

Adorno references Rousseau, Michels, Ibsen, Le Bon, and Freud, along with contemporaries who he regulates, perhaps out of respect for the aforementioned, to footnotes. In another direction, Adorno is competent to discuss the Murray Thematic Appreciation Test and the Berkeley Public Opinion Study Group - the latter, in which he served as a prominent collaborator and leader. Throughout, Adorno ranges in this way from the historical to the theoretical, and relates the two; he is able to extract meaning from the bloodlessly literary as well as the bloodiest of wartime atrocities; his self-consciousness moves from the particular to the universal and back again; he is attuned to the grassroots and to managed public opinion, to party leaders and to Führers; he is conversant with Ancient Greece, Weimar, the Third Reich, and post-war California. Regarded by some as a 'genius,' he is, nonetheless, a model modern democratic citizen, and students of democratic leadership in the Adornoian vein must strive to acquire similarly 'exact imaginations' (see Weber Nicholsen 1997). This entails neither the pose of the selfstyled mandarin or latter-day Tory, nor the mien of the social pathologist or violent revolutionary; neither one a pessimist or optimist; neither one an agitator or resident of the Grand Hotel Abyss. Democratic leadership requires the ability to identify as well as disarm fixed and distorted ideologies and identities, not reproduce yet another variety. Herein lies the pragmatic nonfoundationalism of Mills's 'sociological imagination' (1959) and the 'reflexivity' which Gouldner came to promote (1970).

\section{RESEARCH QUESTIONS}

More than sixty years have passed since Adorno published 'Democratic leadership and mass manipulation,' yet its relevance is arguably undiminished. The basic institutional dynamics of modern mass society have not changed, and earth and its inhabitants homo sapiens and other species - are almost certainly in a worse state of disrepair as a result of the six most recent decades of development. Further technological advancement, further globalization, increasing integration and/or fragmentation of groups and identities from within patched-together societal conglomerations and stereotypes, none of it has changed the basic irrationality which obtains between leaders and mass followers, nor the basically undemocratic nature of the world's principal sustained systems of power and decision. Democratic leadership of the type for which he advocated, of the type Adorno himself practiced, is therefore still needed. We may not live in a time symbolized by the likes of Joseph McCarthy, but is it not true that US Senator Ted Cruz of Texas refers to his US Federal Government colleagues as 'the Washington Cartel' and is no less what Adorno called 'a glorified barker' (p. 434). Ours is a time, not of Roosevelt, Churchill, and Stalin, perhaps, but of Modi, Trump, and Putin; not of NATO, OPEC, and River Rouge, but of EU, ISIS, and ITER; not of Selma, but Ferguson; not of Silent Spring, but Laudato Si. It would be easy to exaggerate the differences, or to ignore them. Exact imaginations resist both.

To renew the struggle against the suppression of democratic leadership in the present, one might just as well consult Studies in Leadership for a conceptualization of the 
most basic and urgent leadership challenge of its age and ours. As Gouldner (1950 [1965]) stresses in his introduction, 'leadership' is only a 'social problem' at all because we hold fast to democratic values and, quite correctly, judge actually existing democracies harshly from their vantage. We teach leadership because, ipso facto, we value democracy, and democracy requires vision and leadership ability of all self-governing people. We assert that leadership can and must be learned, or, as Gouldner puts it, 'acquired,' for the same enlightenment-derived reasons that we believe that democracy is consistent with humanity's self-becoming. The essence of democracy is as Adorno framed it, intellectual autonomy and individual self-determination, which, on a societal level, is tantamount to a system which encourages and protects informed and free self-governance. The latter demands the former and vice versa. Yet, as we know, these ideals are contradicted again and again. More so, irreparable damage has been done. As Adorno (1951 [1987], p. 50) famously observed, contra Hegel, 'the whole is untrue' (das Ganze ist das Unwahre).

The rise of modern democracy was, of course, never independent of other vital, and lethal, forces. In Gouldner's formulation, the 'most relevant' values at risk in modern mass societies 'would seem to be the drive to mastery and control over the environment, a value stimulated by the rise of the triumvirate: Protestantism, modern science, and capitalism' (Gouldner 1950 [1965], p. 5, emphasis in original). Whatever the particulars of its etiology (and various sorts of theorists lay emphases differently), modernity, few would deny, birthed a humanity bent on creation of 'the world as man-controlled,' (Clyde Kluckhohn's formulation quoted favorably by Gouldner (ibid., p. 6)). Gouldner then continues: 'but in a multitude of spheres, the expanding phenomenon of "alienation"7 challenges and undermines this value' (ibid.). That is, modernity's vastly expanded power to control nature and escape its constraints is a pyrrhic victory, costing us much of what can be deemed individual freedom, let alone the free pursuit of meaning in our lives, and, costing us, at a rapidly all-consuming rate, nature as such. In light of these contemporary challenges, we would do well to reacquaint ourselves with the likes of Fromm's Escape from Freedom (1941) and contemplate Francis's 'On care for our common home' (2015).

Broad research questions which emerge from the immediately preceding considerations include:

- In what ways does the continuous reproduction of mass society from out of itself inhibit, perhaps even thwart, democratic leadership development and engagement in our times?

- Resisting debilitating panic, how can advocates of democratic leadership effectively criticize alienation from within so as to unleash potential for genuinely democratic history-making?

- What psychological or other tools are available to provide for the 'level effects' needed to at least problematize the contemporary false consciousness about false consciousness? ${ }^{8}$

7. Gouldner inserts at this juncture the following footnote: 'For a competent discussion of the concept of alienation see Herbert Marcuse, Reason and Revolution (New York, 1941).' Maurice R. Stein, who was a student of Gouldner's during this period, indicates that Gouldner used Reason and Revolution and Erich Fromm's Escape from Freedom (1941) as primary sources in his course on the sociology of fascism. Personal Communication. See Stein (1982).

8. The key source on what Sloterdijk (1988) calls 'reflexively buffered false consciousness.' 
150 Leadership and the Humanities, Vol. 4 No. 2

- Is Laudoto $S i$ an example of the sort of 'manual' imagined by Horkheimer and Adorno? Can well-meaning leaders, even elite leaders, successfully essay against realities so entrenched? ${ }^{9}$

One might continue to spool out any number and variety of subsidiary questions, as one does with any research program. Examples of more focused question include: Does the field of positive psychology, with its attention to non-cognitive factors, offer viable antidotes for our damaged lives?; or, shifting perspective: Is it possible to avert full-scale implementation of geoengineering, the grandest of all would-be technological fixes, or are modern mass societies effectively incapable of the structural and cultural change required by planetary warming? Whatever their scope, the criterion that regulates a question's value is the potential capacity for the research inspired to rend from given systemic distortion and taken-for-granted mendacity the veil of their legitimacy, and in so doing, breathe life into efforts to care for ourselves and, as the Argentine chemist directs, our life-sustaining planet. This is perhaps our calling. Cultivating interiority capable of fulfilling such a calling is as important as promoting institutional and cultural change on a global scale. As Adorno's closest collaborator once not so long ago presciently observed: 'The sole way of assisting nature is to unshackle its seeming opposite, independent thought' (Horkheimer 1947, p. 127).

9. On this, see Abruzzese (2013), including his ruminations on Horkheimer and Adorno's Dialectic of Enlightenment. 


\section{REFERENCES}

Abruzzese, A. (2013), 'The ruling classes and the experience of fear,' Leadership and the Humanities, 1(1), 31-42.

Adorno, T.W. (1950 [1965]), 'Democratic leadership and mass manipulation,' in A.W. Gouldner (ed.), Studies in Leadership: Leadership and Democratic Action, New York: Russell \& Russell, pp. 418-438.

Adorno, T.W. (1951 [1987]), Minima Moralia: Reflections from Damaged Life, New York: Verso.

Adorno, T.W. (1966 [1973]), Negative Dialectics, New York: Continuum.

Adorno, T.W. (1970 [1997]), Aesthetic Theory, Minneapolis, MN: University of Minnesota Press.

Adorno, T.W. (2005), Critical Models: Interventions and Catchwords, New York: Columbia University Press.

Adorno, T.W., E. Frenkel-Bruswik, D. Levinson, and R.N. Sanford (1951 [1993]), The Authoritarian Personality, New York: W.W. Norton \& Company.

Adorno, T.W., H. Albert, R. Dahrendorf, J. Habermas, H. Pilot, and K.R. Popper (1976), The Positivist Dispute in German Sociology, London: Heinemann Educational Books.

Bennis, W. and J. Goldsmith (2010), Learning to Lead, New York: Basic Books.

Benzer, M. (2011), The Sociology of Theodor Adorno, Cambridge, UK: Cambridge University Press.

Bernstein, R.J. (1978), The Restructuring of Social and Political Theory, Philadelphia: University of Pennsylvania Press.

Burns, J.M. (1978 [2010]), Leadership, New York: Harper Perennial Political Classics.

Choi, S. (2007), 'Democratic leadership: the lessons of exemplary models for democratic governance,' International Journal of Leadership Studies, 2(3), 243-262.

Claussen, D. (2003 [2008]), Theodor W. Adorno: One Last Genius, Cambridge, MA: Harvard University Press.

Dandaneau, S.P. and M. Falcone (1998), A Wrong Life: Studies in Lifeworld-Grounded Critical Theory, Westport, CN: JAI Press.

Francis (2015), 'Encyclical letter Laudato Si of the Holy Father Francis on care for our common home,' available at: http://w2.vatican.va/content/francesco/en/encyclicals/documents/papafrancesco_20150524_enciclica-laudato-si.html (accessed July 26, 2015).

Frankfurt Institute for Social Research (1973), Aspects of Sociology, with a Preface by M. Horkheimer and T.W. Adorno, Boston: Beacon Press.

Fromm, E. (1941), Escape from Freedom, New York: Holt, Rinehart, and Winston.

Geuss, R. (1981), The Idea of a Critical Theory: Habermas and the Frankfurt School, Cambridge, UK: Cambridge University Press.

Gilman, N. (2006), 'The prophet of Post-Fordism: Peter Drucker and the legitimation of the corporation,' in N. Lichtenstein (ed.), American Capitalism: Social Thought and Political Economy in the Twentieth Century, Philadelphia: University of Pennsylvania Press, pp. 109-134.

Gouldner, A.W. (ed.) (1950 [1965]), Studies in Leadership, New York: Russell \& Russell.

Gouldner, A.W. (1970), The Coming Crisis of Western Sociology, New York: Basic Books.

Heifetz, R. and M. Linsky (2002), Leadership on the Line, Boston: Harvard Business Review Press.

Horkheimer, M. (1937 [1972]), 'Traditional and critical theory,' in M. Horkheimer, Critical Theory: Selected Essays, New York: Continuum, pp. 188-243.

Horkheimer, M. (1947), Eclipse of Reason, Oxford: Oxford University Press.

Horkheimer, M. and T.W. Adorno (1944 [2007]), Dialectic of Enlightenment, Palo Alto, CA: Stanford University Press.

Jameson, F. (2007), Late Marxism: Adorno, or, The Persistence of the Dialectic, London: Verso.

Jay, M. (1973), The Dialectical Imagination: A History of the Frankfurt School and the Institute for Social Research, New York: Little, Brown.

Marcuse, H. (1937 [1968]), 'Philosophy and critical theory,' in Negations: Essays in Critical Theory, Boston: Beacon Press. 
152 Leadership and the Humanities, Vol. 4 No. 2

Marcuse, H. (1941), Reason and Revolution: Hegel and the Rise of Social Theory, New York and Oxford: Oxford University Press.

Marcuse, H. (1964), One-Dimensional Man: Studies in the Ideology of Advanced Industrial Society, Boston: Beacon Press.

Mariotti, S.L. (2013), 'Adorno on the radio: democratic leadership as democratic pedagogy,' Political Theory, 42(4), 415-442, doi: 10.1177/0090591713505093.

Mills, C.W. (1959), The Sociological Imagination, Oxford: Oxford University Press.

Müller-Doohm, S. (2005), Adorno: A Biography, Cambridge, UK: Polity Press.

Nicholsen, S.W. (1997), Exact Imagination, Late Work: On Adorno's Aesthetics, Cambridge, MA: MIT Press.

Pensky, M. (ed.) (1997), The Actuality of Adorno: Critical Essays on Adorno and the Postmodern, Albany, NY: SUNY Press.

Said, E.W. (2007), On Late Style: Music and Literature Against the Grain, London: Vintage.

Sloterdijk, P. (1988), Critique of Cynical Reason, Minneapolis, MN: University of Minnesota Press.

Stein, M.R. (1982), 'The dialectic of Marxism and sociology during the Buffalo years,' in Theory \& Society, 11(6), pp. 889-897.

Wiggershaus, R. (1994), The Frankfurt School: Its History, Theories, and Political Significance, Cambridge, MA: MIT Press.

Wolin, R. (2006), The Frankfurt School Revisited, New York: Routledge. 